\title{
SCIENCE MUST PUT ITS HOUSE IN ORDER, ETHICS FORUM PARTICIPANTS CONCLUDE
}

\author{
A Summary of the 1993 Sigma Xi Forum \\ Ethics, Values, and the Promise of Science
}

When it comes to ethical issues in science, the scientific community must put its house in order or face possible outside regulation that could ultimately impede scientific progress. This was a common theme expressed by National Research Council (NRC) ethics panel chair Edward E. David, Jr. and other speakers at a forum on Ethics, Values, and the Promise of Science, held in San Francisco February 25-26.

As David said after describing the work of the NRC panel which he chaired, "My own addendum is that the [scientific] establishment must now move forward resolutely... Lacking that, the scientific community's traditional self-governance [with regard to issues of misconduct] will be increasingly in jeopardy."

"The David Report," as it has come to be called, sought to define misconduct in science and offer a definitive response from the scientific community, in the wake of a series of widely publicized cases of misconduct by prominent researchers. Sponsored by Sigma Xi, The Scientific Research Society, the conference on ethics and science was attended by more than 450 scientists and engineers from across the country, as well as leaders from government, industry, the humanities and the media.

Together, they developed more than 20 conclusions and recommendations for the scientific community on ethical issues, many of which placed the responsibility for improving the public image of science on scientists themselves. The recommendations have been distributed to Sigma Xi's approximately 100,000 members and will provide a starting point for an ongoing interdisciplinary program on ethics and values in research under development for the proposed Sigma Xi Center in Research Triangle Park, N.C. The forum proceedings volume published by Sigma Xi represents a valuable addition to the field of professional ethics.

At the forum, talks by Nobel laureates J. Michael Bishop, Yuan T. Lee, Steven Weinberg and Rosalyn S. Yalow further defined ethical research principles and practices. "While we struggle to balance the promise of science with social conflict, we must confront another challenge: disquiet about the stewardship of science," Bishop said. "Fear, bewilderment, disdain: these are all opponents science must best. And there is one other, which is now current: mistrust."

One of the primary goals of the forum was to develop recommendations on actions researchers can take to help restore what many perceive to be eroding public confidence in science. "In the seesaw of history, a new agent has entered the equation, a weight unlike any in the whole history of the rise and fall of the perceived value of science itself," said Harvard University physicist and science historian Gerald Holton. "It is the assertion that the pursuit of science is, and has been all along, corrupt and crooked; and that consequently severe measures must be applied to the practice of science from outside.

"A second element has been added to the generalized charge of the rotten barrel rather than the occasional rotten apple," he continued. "The most basic fraud is one the scientific community commits as a whole-the claim that there is any truth to be found at all. There is nothing there to falsify."

"There can be little doubt that science is at a crossroads," said keynote speaker George Bugliarello, president of Polytechnic University. "Old compacts between science and the rest

-more-

ASTRBBUTION OF THIS DOCUMENT IS UNLMITED 


\section{DISCLAIMER}

This report was prepared as an account of work sponsored by an agency of the United States Government. Neither the United States Government nor any agency thereof, nor any of their employees, makes any warranty, express or implied, or assumes any legal liability or responsibility for the accuracy, completeness, or usefulness of any information, apparatus, product, or process disclosed, or represents that its use would not infringe privately owned rights. Reference herein to any specific commercial product, process, or service by trade name, trademark, manufac: turer, or otherwise does not necessarily constitute or imply its endorsement, recommendation, or favoring by the United States Government or any agency thereof. The views and opinions of authors expressed herein do not necessarily state or reflect those of the United States Government or any agency thereof. 


\section{DISCLAIMER}

Portions of this document may be illegible in electronic image products. Images are produced from the best available original document. 


\section{Page 2}

of society are questioned by a world that often has seen hopes for social progress deluded in spite of science's magnificent achievements and promise."

"In the early days of scholarly science, the field was chosen as a personal career for its intellectual rewards, like art," said Chauncey Starr, president emeritus of the Electric Power Research Institute. "Today, science is an institutionalized industry. However, science is not an entitlement program for scientists, demanding society's support. The support of science should be deserved by its contributions to our national needs, and balanced against other social goals."

Many perceive science as being somewhat aloof from the rest of society, which in itself has fostered skepticism and mistrust. "Producing Ph.D.'s is simply not the purpose of our system of education," California Institute of 'Technology Vice Provost David L. Goodstein said in a talk titled Scientific Elites and Scientific Illiterates. "Its purpose instead is to produce citizens capable of operating a Jeffersonian democracy, and also if possible, of contributing to their own and to the collective economic well being.

"There must be a broad political consensus," Goodstein continued, "that pure research in basic science is a common good that must be supported from the public purse. There must also be genuine education in science, not just for the scientific elite, but for all the citizens who must form that broad political consensus."

Several speakers expressed the view that underscoring the ethical principles and practices upon which research should be based is necessary to bring science back into the fold. Yet, medical ethicist Bernard Lo of the University of California at San Francisco pointed out that many scientists are skeptical that ethics can or should be taught. "Only unethical persons have ethical problems. Ethics is a matter of common sense and experience. Therefore, studying ethics isn't useful," he said, summarizing some commonly held views in the scientific community.

Lo, who heads the UCSF Medical Ethics Program, maintained that students usually learn more when they think the issues through for themselves, by becoming involved in case studies that mirror ethical dilemmas they may face in their own careers.

Another facet of the conference was devoted to the peculiar plight of post-doctoral fellows in the academic system. A panel of four postdocs from local universities talked about the vulnerability of being neither student nor faculty, and hence totally beholden to their professor. They said postdocs often find themselves somewhere between indentured servitude and slavery and noted that a good professor is a mentor for life; whereas a bad professor can destroy the postdoc's career.

Forum conclusions and recommendations covered such topics as institutional responses to misconduct in science, definitions of misconduct, science and the media, the peer review process, the ethics of diversity, improving mentoring, the societal responsibilities of science, and teaching ethics. They included:

- Peer review in scientific publication should be retained because it serves science better than any alternative system. Nevertheless, peer review has severe problems that need to be investigated and remedied. Authors and their institutions should never be identified to journal referees.

- Scientific misconduct is an outgrowth of mismanagement or a lack of proper supervision. In responding to allegations of misconduct, institutions should seek to ascertain why or how misconduct was allowed to occur.

-more- 
Page 3

- Significant problems exist in mentor relationships and the problems are widespread. Major reluctance exists among mentors, their students and institutions toward addressing these problems.

- The definition of misconduct in science is designed to determine which behavior is to be sanctionable by the scientific misconduct apparatus of federal agencies. Included in misconduct are fabrication, falsification, plagiarism and other deliberate misrepresentation in proposing, performing, reporting or reviewing research.

- Scientists and journalists have a mutual responsibility for accurate, open and balanced information. Scientific issues can rapidly escalate into social, ethical and political issues. Workshops for scientists on interacting with the media and briefings by scientists for journalists would help increase the flow and improve the clarity of information from scientists to journalists.

- Appropriate ethical behavior needs to be communicated to and practiced at all levels of academic, governmental, industrial and other research organizations associated with science and engineering. Ethics should be taught as an integral component of formal scientific education, in cooperation with technical professionals and scholars in the humanities.

- Scientists must increase their educational efforts to convey an understanding of their work to the lay public, to participate more directly in the political process, and to exercise the highest ethical standards in their work.

- Women, persons of color, the physically challenged and others from diverse cultures are inadequately represented in the community of scientists and engineers. A partial list of barriers that prevent upward mobility includes a lack of mentoring, uneven granting of government research funding, unequal financial remuneration and delayed advancement and promotion. The increased inclusion [of underrepresented groups] need not, and must not, adversely affect the high standards of excellence that characterize the modern scientific enterprise. The scientific community must be open and receptive to new ideas and novel approaches to science that will inevitably accompany increased diversity among scientists.

- Science must fully disclose to the public its capabilities, limitations, and participating role in solving today's social and ethical issues.

Funding for the 1993 Sigma Xi Forum was provided by Abbott Laboratories, the Bechtel Foundation, Carolina Power \& Light Company, Ciba-Geigy Corporation, Corning Incorporated, the Electric Power Research Institute, the General Electric Foundation, Glaxo Inc., the Johnson Foundation, the Lucille P. Markey Charitable Trust, Monsanto Company, the Office of Naval Research, the David and Lucile Packard Foundation, the Alfred P. Sloan Foundation, Texaco Inc., the U.S. Department of Energy, the U.S. Environmental Protection Agency and the Weingart Foundation.

Founded in 1886, Sigma $\mathrm{Xi}$ is comprised of more than 500 chapters and clubs at universities and colleges, government laboratories and industry research centers. In addition to sponsoring national forums on research topics, Sigma Xi publishes American Scientist magazine and awards research grants annually to hundreds of promising graduate and selected undergraduate students to further their careers.

The 1994 Sigma Xi Forum Scientists, Educators, and National Standards: Action at the Local Level, to be held in Atlanta next April 14-15, will focus on fostering and strengthening partnerships between scientists and educators, with the aim of preparing K-12 students for national science education standards. 